\title{
Key Persons
}

Basu

Chagö Tomden

Che Jigme

Cheng Jingbo

Chen Yi

Chömpel

Dawa

Deng Xiaoping

Dramdul
Head of the Indian Communist Party in Calcutta

A leading Tibetan official from Derge in Kham

A leading official in the Panchen Lama's administration

PLA official and Phünwang's secretary

Marshal in the PLA and vice premier of the PRC

Phünwang's brother

Childhood friend of Phünwang and member of the Tibetan Communist Party

Political commissar of the Southwest Military and Administrative Bureau; later paramount leader of the PRC

Khampa from Batang; original member of the Spark Association in Derge 
Fan Ming

Fei Delin

Fu Dequan

Gora Ashi

Gyalo Thondup

He Long

Hua Guofeng

Hu Yaobang

Janglojen

Kapshöpa Sey

Kesang Tsering

Kheme

Lhalu

Li Jingquan

Liu Bocheng

Liu Chun

Liu Geping
Important Northwest Bureau official who was deputy secretary of the Tibet Work Committee in Lhasa

First secretary of the Soviet Embassy in China and Phünwang's main Soviet contact

Guomindang military commander in Batang

Phünwang's father

The Dalai Lama's older brother

Marshal in the PLA and vice premier of the PRC

Chairman of the CCP after Mao's death

Reformist general secretary of the CCP in the I980s

Progressive Lhasa aristocrat

Progressive Lhasa aristocrat

Tibetan who led a revolt against the local Chinese authorities in Batang

Commander in chief of the Tibetan army and participant in SeventeenPoint Agreement negotiations

Governor-general in Chamdo after Yuthok and member of the Kashag (Council of Ministers)

Head party secretary in Sichuan Province

Head of the Southwest Military and Administrative Bureau A deputy director of the State $\mathrm{Na}$ tionalities Affairs Commission A deputy director of the State $\mathrm{Na}$ tionalities Affairs Commission; in- 
Liu Shaoqi

Liushar (Thubden Tharpa)

Liu Wenhui

Li Weihan

Lobsang Thundrup

Lukangwa

Ngabö

Ngawang Kesang

Ou Gen

Panda Tobgye

Peng Dehuai

Peng Zhen

Phüngang vestigated the implementation of reforms in Sichuan in 1956

President of the PRC

Senior Tibetan aristocratic official Chinese warlord who ruled Kham (Xikang)

Senior party official involved in nationalities affairs; head of the Chinese delegation to SeventeenPoint Agreement negotiations and director of the United Front Work Department

Phünwang's uncle who was sent to Batang from Nanjing by Chiang Kaishek in 1935 and led an uprising there

Anti-Chinese acting prime minister of Tibet, 1950-1952

Tibetan council minister and governor-general in Chamdo when the PLA attacked; head of the Tibetan delegation to the Seventeen-Point Agreement negotiations in Beijing Phünwang's classmate and friend; early member of the Tibetan Communist Party

Commander of communist forces in Yunnan in 1949

Khampa leader and businessman

Head of the Northwest Military and Administrative Bureau and a marshal in the PLA

Chairman of the standing committee of the NPC and Politburo member

Phünwang's eldest son 
Phüntso Tashi

Ragashar

Sherap

Shökhang

Sun Yatsen

Surkhang

Tharchin Babu

Topden

Trendong Sey

(Tomjor Wangchuk)

Trinley Nyima

Tsadrü Rimpoche

Tseden Yangdrön

Tsilila

Tsögo

Ulanhu
The Dalai Lama's brother-in-law and general in the Tibetan army Aristocrat and member of the Kashag (Council of Ministers)

Phünwang's friend at school; early member of the Tibetan Communist Party

Progressive Lhasa aristocrat

Father of the Chinese revolution against the Manchu dynasty Aristocrat and member of the Kashag (Council of Ministers)

Publisher of the Tibetan Mirror, a Tibetan-language newspaper in Kalimpong

Phünwang's younger brother One of the first Tibetan cadre; joined the Long March as it passed through Kham

Khampa from Batang; original member of the Spark Association in Derge

Progressive Lhasa aristocrat and close friend of Phünwang Khampa member of the Tibetan Communist Party

Well-known Tibetan lama and scholar

Phünwang's second wife

Phünwang's first wife

Tibetan aristocrat who was

Ngabö's aide in Chamdo

Ethnic Mongolian who was director of the United Front Work

Department 
Wang Feng

Wang Guangmei

Wang Qimei

Wu Zhong

Xi Zhongxun

Xu Danlu

Xue Jianhua

Ya Hanzhang

Yang Jingren

Yangling Dorje

Ye Jianying

Yin Fatang

Yuthok

Zhang Guohua
A deputy director of the State Nationalities Affairs Commission Wife of Liu Shaoqi

A senior commander in the $\mathrm{I} 8$ th Army in Tibet

Commander of the 52nd Division of the I8th Army

A high party official from the Northwest Bureau who was involved in nationalities affairs and became vice premier of the PRC

Head of intelligence operations for the I8th Army in Tibet

Director of the Nationalities Bureau of the United Front Work

Department

Northwest Bureau cadre who was a member of the Tibet Work Committee in Lhasa

Head of the State Nationalities Affairs Commission in the early I980s

Tibetan cadre from Batang who was a deputy secretary in the TAR government in the I970s and I980s

Senior official at the 8th Route Army office in Chongqing in I939-I940

I 8th Army officer who was head of the party branch office in Gyantse in the I950s; in I980, became the head party secretary of the TAR

Tibetan governor-general of Chamdo

Commander of the I8th Army and 
Zhang Jingwu

Zhao Ziyang

Zhou Enlai

Zhu Dalfen

Zhu De deputy secretary of the Tibet Work Committee in Lhasa

Representative of the Central Committee to Tibet and head of the Tibet Work Committee in Lhasa

Premier and member of the Standing Committee of the Politburo Premier of the PRC

Well-known Chinese revolutionary writer and publisher

Commander in chief of the PLA 


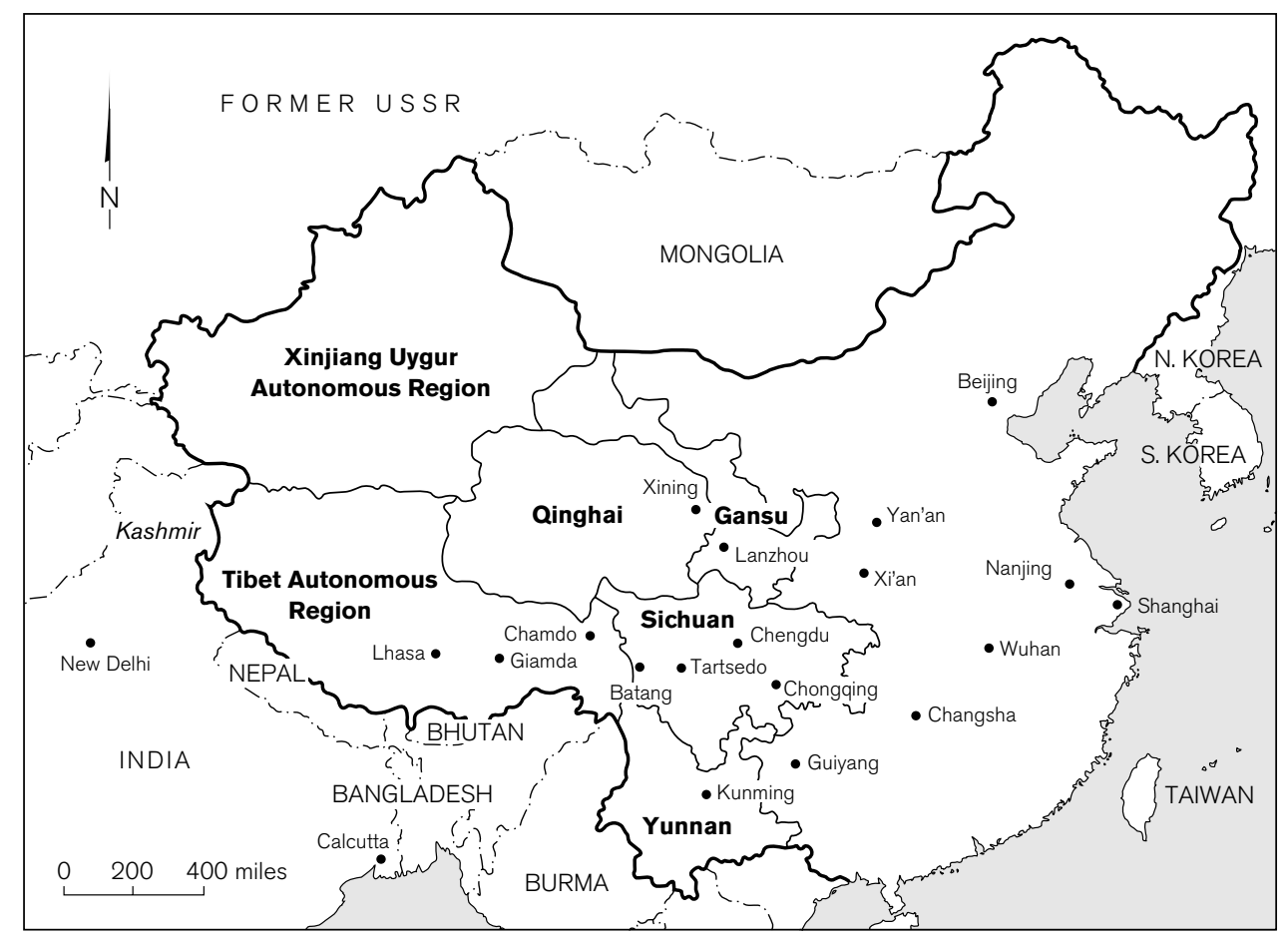

Map I. China and surrounding areas. 


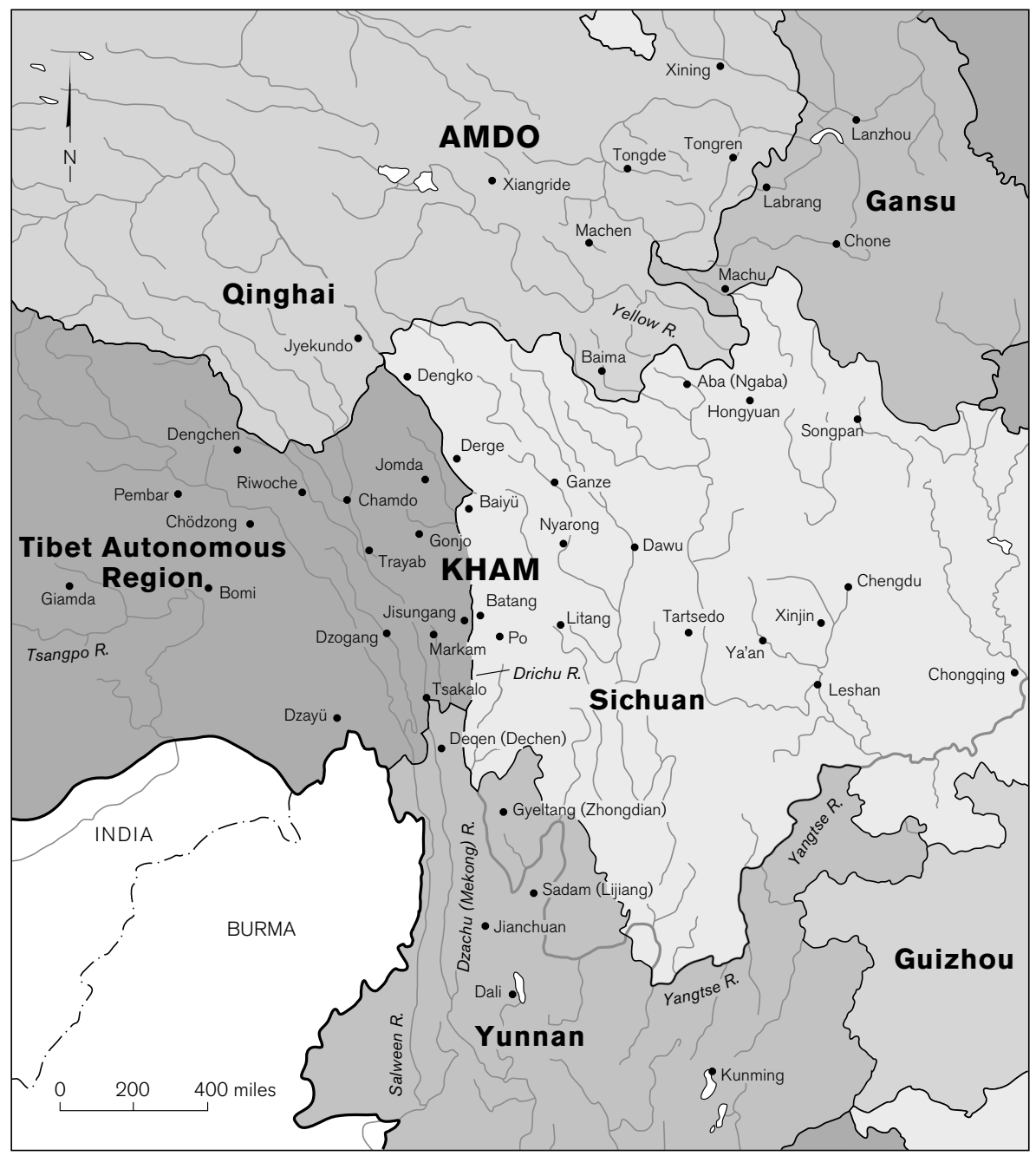

Map 2. Eastern Tibet. 


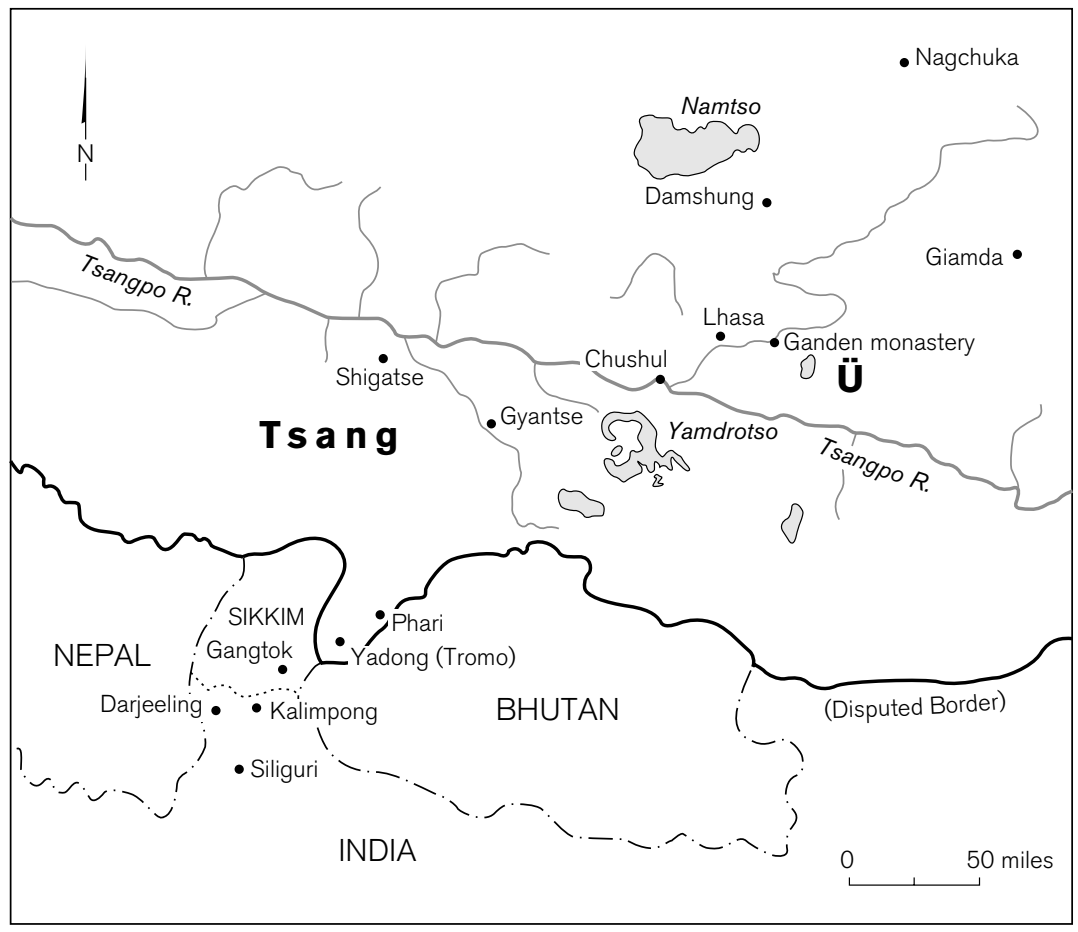

Map 3. Central Tibet. 
This page intentionally left blank 